\title{
Ants Oras and the Analysis of Early Modern English Dramatic Verse
}

\author{
MacDonald P. Jackson*
}

\begin{abstract}
Ants Oras's contribution to the study of early modern English dramatic verse is of enduring value. In 1956 his article on extra monosyllables in Henry VIII gave much needed support to the view that both this play of the Shakespeare First Folio (1623) and The Two Noble Kinsmen (first published in a quarto of 1634) were works in which Shakespeare had collaborated with John Fletcher. Oras's Pause Patterns in Elizabethan and Jacobean Drama (1960), with its huge amount of quantitative data and readily intelligible graphs, greatly enhanced understanding of how blank verse developed from the 1580s to the closing of the London theatres in 1642. Moreover, use of Oras's techniques of analysis has continued to throw light on questions of chronology and authorship surrounding Shakespeare and his fellow playwrights. Among plays illuminated in this way have been The Revenger's Tragedy, Pericles, Thomas of Woodstock, Sir Thomas More, and Arden of Faversham.
\end{abstract}

Keywords: Ants Oras, early modern, English drama, Shakespeare, blank verse, extra monosyllables, pause patterns, chronology, authorship, Marina Tarlinskaja

Mark Antony's address to his "Friends, Romans, countrymen”, after Caesar's assassination, has seldom been more effectively delivered than by Marlon Brando in Joseph Mankiewicz's movie of 1953. But in the week leading up to the filming Brando was anxious. He had no sense of how Shakespeare's blank verse should be spoken, or of the principles on which it was based. He sought help from the production's Cassius, John Gielgud, who explained the basic pattern of alternating stressed and unstressed syllables. Only after repeated lessons did Brando begin to hear the iambic beat (Gielgud 1979: 193-194).

Brando is celebrated as among the greatest stars of the screen, rather than of the stage. He was wise to seek instruction on Shakespeare's verse from a master of the art of speaking it. But these days many professional theatre actors, even at London's restored Shakespeare's Globe, have a poor grasp of the workings of iambic pentameter, without even realizing their ignorance. Mispronunciations that an ear for the metre would have deterred are common: "like Nióbe all

\footnotetext{
* Author's address: MacDonald P. Jackson, English Department, University of Auckland,
} Private Bag 92019, Auckland Mail Centre, New Zealand, email: m.jackson@auckland.ac.nz. 
tears", with the accent on the second syllable, instead of the first, for example. Gielgud or Olivier would never have made such mistakes.

An interest in prosody has not characterized the last fifty years of Shakespeare studies, though there have been a few good books on the subject, notably by George T. Wright and Peter L. Groves. But the most comprehensive and impressive analyses of early modern English dramatic blank verse have been by the Russian-trained Marina Tarlinskaja, and in one major aspect of her research her most illuminating predecessor was the great Estonian scholar Ants Oras. I have admired his work for over half a century.

Among my earliest publications was an analysis of affirmative particles in Henry VIII, included in the Shakespeare First Folio of 1623, and The Two Noble Kinsmen, attributed to Shakespeare and Fletcher in a quarto of 1634 (Jackson 1962). Several prominent Shakespeareans - including Peter Alexander, Hardin Craig, G. Wilson Knight, and R. A. Foakes - had challenged the long-established view that Fletcher had, during Shakespeare's final years as a dramatist, collaborated with him on these plays. I showed that throughout his playwriting career Shakespeare preferred "Ay" to "Yes", reserving the latter for special emphasis and the contradiction of negatives, whereas the younger Fletcher avoided "Ay" and favoured "Yes" in all situations. The distribution of the two forms, and of the intensive "Yea", within Henry VIII and The Two Noble Kinsmen supported the orthodox division of scenes between the two authors. Familiarizing myself with the relevant academic publications, I had encountered Oras's excellent article on "extra monosyllables" in the two collaborative plays (Oras 1953). It was well known that Fletcher was far fonder than Shakespeare of the feminine ending, an extra unstressed syllable at the end of an iambic pentameter line, and that Fletcher's fondness seemed to be reflected in certain scenes of Henry VIII and The Two Noble Kinsmen that also exhibited traces of his phraseology. But Alexander and others had argued that a tendency for feminine endings to appear more frequently during Shakespeare's late period was intensified in Henry VIII, which followed The Tempest. Oras set out to show that this explanation would not serve.

Examining the three Shakespeare plays written immediately before Henry VIII (which can be dated 1613) and The Two Noble Kinsmen (1613-1614) ${ }^{1}$ and three Fletcher plays of the same period, Oras demonstrated that there was a highly significant difference between the two playwrights in their proportions of feminine endings that were composed of monosyllables, rather than of the

\footnotetext{
1 When dates in parentheses are not clearly of publication, they are for first performance as determined in Wells and Taylor 1987 (for plays by Shakespeare) or Harbage et al. 1987 (for other plays).
} 
final syllable of a word of two or more syllables; and that to the quantitative difference could be added a qualitative one: Fletcher often, but Shakespeare never, employed words of some weight, such as nouns, as the redundant end-ofline monosyllable. And these and further distinctions carried over into those scenes that had been ascribed on other grounds to Fletcher or Shakespeare in the plays whose authorship was now in dispute. There could be no doubt that the scenes fell into two contrasting authorial groups. Oras's article was a model of clear, detailed, logical exposition.

Oras's supreme contribution, however, to the study of dramatic blank verse was his monograph, Pause Patterns in Elizabethan and Jacobean Drama (1960). His aim was "to examine verse as such, for its own sake, as one of the principal elements contributing to the total impact of Renaissance drama and determining the special nature of the impression that drama creates" (Oras 1960: 1 ). Working from the early printed texts, he counted, in the plays of all the main dramatists and several of the lesser ones, the number of times in which punctuation marked pauses within each of the nine syllabic positions within iambic pentameter lines. He obtained separate figures for (a) all punctuation, (b) punctuation heavier than commas, and (c) syntactical breaks caused by the sharing of lines between two or more speakers. He was well aware that scribes and compositors were responsible for much of the punctuation in the surviving texts, but rightly believed that authorial syntax and rhythm underlay their choices. Moreover, the decision to divide a line between speakers was clearly the author's, and pauses created in this way formed patterns closely resembling those indicated by commas, semi-colons, colons, and so on. His interest was in the percentages of all internal pauses that fell in each position. Authors and agents in the transmission of the text might, he believed, deliberately choose to use little or much pausation in their verse, but the patterns formed by the placing of pauses would be less subject to conscious control and so might be as personal as "cardiograms" (Oras 1960: 2).

Oras proved beyond doubt that - from the opening of the Theatre in 1576 to the closing of the theatres in 1642 - there was an overall development in dramatic verse, in which individual playwrights participated in their own distinctive ways. Graphs illustrated his results. For instance, Shakespeare's early plays displayed a high peak in the proportion of pauses after position four; for his middle plays there were two lower and roughly equal peaks after positions four and six; while his late plays exhibited a dominant peak after position six. The general trend was for pauses to occupy later and more diverse positions in the line. The proportions after uneven syllables increased.

Oras preceded his analysis of dramatic verse with illuminating figures and graphs for some French and Italian poets and from Chaucer and Spenser, and 
he discussed the implications of his findings with characteristic astuteness. His data are a rich mine of information for those concerned with questions of attribution and chronology. There are mathematical methods, described in all textbooks on statistics, for calculating the degrees of likeness between any two of Oras's graphs. One is the Basic Linear Correlation. ${ }^{2}$ In 1993, Oxford University Computing Services, provided with Oras's raw figures for type-a pauses, created for me a matrix of correlation coefficients between every pairing of plays by Shakespeare. In 2002 I finally reported these results (Jackson 2002a). They were astonishing. When the plays were listed in chronological order of their dates of composition according to the Oxford edition of Shakespeare's Complete Works, ranging from 1590-1591 to 1613-1614, in twenty-eight out of thirty-eight cases a play's pause patterns were most closely correlated to those of another that had been written within a year and a half of it, the average distance being less than a year (Wells and Taylor 1987: 109-134). For a further five the closest correlation was with a play separated from it by not more than three years. For only five plays were the results slightly anomalous, and the anomalies were easily explained. For example, The Merry Wives of Windsor (dated 1597) was most similar to Troilus and Cressida (1602): not only does Merry Wives contain very little verse, and the smaller the sample the greater the influence of purely random factors, but also the revised chronology of the forthcoming New Oxford Shakespeare makes the two plays adjacent. ${ }^{3}$ It would be idle to suppose that artistic change must always be a matter of steady, linear, one-way progression, but something approaching this kind of regularity evidently governed Shakespeare's disposition of pauses within his blank verse lines.

Antony and Cleopatra (1606) was most closely correlated to The Tempest (1611) and vice versa, but a glance at the inter-correlations among plays from 1606 onwards reveals that Antony and Cleopatra ushered in a final phase of Shakespeare's rhythmical style, so that even the five-year gap between Antony and The Tempest, so similar in their pause patterns, is unsurprising.

Among the problems of authorship on which Oras's data threw light was that of The Revenger's Traged $y .{ }^{4}$ The traditional attribution to Cyril Tourneur originated in an utterly unreliable seventeenth-century bookseller's catalogue, but in the 1960s resistance to the case that had been made for identifying

2 The test is described at VassarStats (see references), where calculations can be carried out electronically.

3 Private communication from Gary Taylor, 28 March 2015.

4 Full details about the play are available in Taylor and Lavagnino 2007: 360-363. 
Middleton as the author remained strong. Oras's graph of the pause patterns in the one extant play undoubtedly Tourneur's assumed an almost unique shape, quite unlike that for The Revenger's Tragedy, which was very like graphs for Middleton's comedies of the appropriate period (Oras 1960: 58). Calculating correlation coefficients, I found that in fact every one of Middleton's thirteen unaided plays provided a closer fit to The Revenger's Tragedy than did The Atheist's Tragedy, and that closest of all was A Trick to Catch the Old One, which had been coupled with The Revenger's Tragedy in a Stationer's Register entry of 7 October 1607 - a coupling that appeared to be confined to plays by the same author (Jackson 1983: 28-29).

Oras's figures again supplied me with useful material with which to bolster the case for regarding Pericles - excluded from the First Folio (1623) collection of Shakespeare's plays but published as his in a quarto of 1609 - as a work of co-authorship, to which the minor playwright George Wilkins had contributed the first two acts. Competing hypotheses were that Shakespeare was solely responsible, but had some special reason for beginning the play in an unusual style, or that the first two acts were remnants from a version he had written at the beginning of his career. Oras's gave separate figures for the first two and last three acts of Pericles (dated 1607), but he did not offer any for The Miseries of Enforced Marriage (1606), the only surviving play entirely by Wilkins. But Oras carefully defined his principles of computation and in trials of my own I found that I could replicate his results, so was able to compile type-a figures for Miseries. When these were graphed, in Oras's manner, alongside those for Shakespeare's Coriolanus (1608), it was obvious that Pericles, 1-2, matched Miseries and was unlike Pericles, 3-5, and Coriolanus, which were almost identical to each other. The shape of the graph for Pericles, 1-2, with its double peak for positions four and six also undermined the theory that this was early Shakespearean writing (Jackson 2003: 87).

Computing pause patterns in Oras's manner also furnished me with ammunition in arguing that the anonymous manuscript play Thomas of Woodstock, usually dated 1592-1593 and supposed to have been a "source" for Shakespeare's Richard II (1595), was in fact written in the seventeenth-century, probably by Samuel Rowley (Jackson 2002b). David J. Lake had proved that the existing manuscript must have been penned no earlier than 1600, but, accepting the orthodox dating of the play, he had assumed that the contractions and other linguistic forms that established as much had been introduced by a scribe who subjected the original script to "creative revision" (Lake 1983). I put forward evidence that not only the linguistic forms of Thomas of Woodstock but also its metrical characteristics and its vocabulary pointed to its having been first composed long after the early 1590s. Among features of the verse at odds 
with the orthodox dating was the distribution of internal pauses. Here again, a graph displayed peaks in positions four and six. None of Oras's graphs for plays written in the 1580 s or early 1590 s had a remotely similar configuration. Greene, Kyd, Lodge, Lyly, Marlowe, Peele, the early Shakespeare, Wilmot, and the anonymous contemporary playwrights whose verse Oras scrutinized all had very different graphs, with peaks at position four.

The twin peaks of Thomas of Woodstock also emerged from an examination of the manuscript of the original Sir Thomas More, which was revised by several playwrights, including Shakespeare, who contributed a new scene (Jackson 2002b). The unrevised script of More had also been dated to the early 1590s. John Jowett had given good reasons for thinking that it was the joint work of Antony Munday, in whose handwriting it survived, and Henry Chettle (Jowett 1989). In Chettle's share the highest number of pauses, counted in Oras's manner, came after the sixth syllable, which suggested a date closer to 1600. Shakespeare's evolution in this matter was fairly typical: the first play of his in which pauses after the sixth syllable exceeded pauses after the fourth was Twelfth Night (1601). Munday's share of the original More was metrically less advanced than Chettle's, but the pausation was nevertheless suggestive of a date nearer to 1600 than to 1590 . In this case too, linguistic forms supported the later dating.

Oras triumphantly succeeded in his aim of enhancing "the understanding of what Renaissance verse is and of the factors that made it develop the way it did" (Oras 1960: 1). Decades beforehand, E. H. C. Oliphant had proclaimed the importance to his pronouncements on questions of authorship in the drama of Shakespeare's time of various idiosyncrasies of vocabulary, syntax, and "the facture of the verse into which [...] sentences are moulded", above all "the indefinite music that permeates it all" or "the rise and fall of the melody, proceeding one hardly knows whence, but mainly doubtless from the distribution of stresses" (Oliphant 1927: 30-31). Oras discovered a means of quantifying and defining one aspect of Oliphant's "indefinite music", but not that derived from "the distribution of stresses". The task of methodically analysing patterns of stress was taken up by Marina Tarlinskaja, who has also refined Oras's research on pauses, and has added quantitative data on "word boundaries" and many miscellaneous elements to the prosodist's armoury (Tarlinskaja 1987; 2014).

Whereas Oras relied on punctuation as an indicator of pausation, Tarlinskaja has studied "strong syntactic breaks" in iambic pentameter verse, relying on a linguist's sense of the actual syntax. The overall patterns of Tarlinskaja's breaks and Oras's pauses are not dissimilar, but the diversity of Tarlinskaja's measures of versification make for greater confidence in her judgements on the date and 
authorship of any shorter piece of verse, in particular. She undertakes a much fuller analysis of Munday, Chettle, and their shares of the original Sir Thomas More than application of Oras's methods, cited above. Her research confirms my own conclusion, reported by Taylor (1989: 120) that pause patterns assign the famous Shakespearean "Hand D" addition to More was made within the period from Twelfth Night (1601-1602) to Macbeth (1604-1605): she settles on 1603-1604 as a probable date (Tarlinskaja 2014: 176-192).

Tarlinskaja's wider range of tests may yet help solve the problem posed by the Melbourne MS, a four-page fragmentary draft of a play-scene discovered in 1985 at Melbourne Hall, Derbyshire (Jackson 2006). It bears some relation to James Shirley's The Traitor (1631), 1.2, and a range of evidence suggests that it is Shirley's discarded draft. But arguments have also been advanced for denying it to Shirley and concluding that John Webster wrote it around 1606-1609. We have absolutely no handwriting by Webster, and a palaeographical case for Shirley, trained as a scrivener, founders on the instability and variety of his penmanship. A graph of the fragment's pause patterns more closely resembles Oras's graph for Shirley's Hyde Park (1632) than any of his graphs for Webster, but this is a "poor likelihood". The manuscript scene was clearly composed by an exceptionally talented dramatist. It is desirable that he be more securely identified.

Let me end with an illustration of the efficacy of Tarlinskaja's refined version of Oras's pause patterns (namely "strong syntactic breaks"), along with word boundaries, stressing on "strong syllabic positions", and miscellaneous additional features as aids to the determination of authorship. The case study is the domestic tragedy Arden of Faversham, published anonymously in 1592. Employing computerized stylometric tests, based on lexical words and highfrequency function words used more and less often by Shakespeare than by other playwrights, Hugh Craig and Arthur F. Kinney (2009: 78-99), came to the decision that scenes 3-9 of the tragedy Arden of Faversham (published anonymously in 1592) were largely, if not wholly, by Shakespeare. In a recent study I advanced independent reasons for endorsing this verdict (Jackson 2014).

Tarlinskaja herself proposes that the versification of scenes 3-8 is compatible with a Shakespearean provenance (2014: 105-111). She also accepts the conclusions of recent attribution studies that Titus Andronicus and 1,2, and 3 Henry VI are collaborative works, and that the anonymous Edward III (published 1596) was partly Shakespeare's. She gives separate data for the "Shakespearean" and "non-Shakespearean" portions of these plays, and for 1 Henry VI separate figures for Act 1, attributed to Thomas Nashe, and the remaining scenes that are not judged to be by Shakespeare (Tarlinskaja 2014: Tables B.1-B.4). In a forthcoming article I report the outcome when 
statistical tests are applied to her figures, in order to determine whether the Shakespearean scenes of Arden of Faversham are closer to the Shakespearean or non-Shakespearean scenes of the five early Shakespearean collaborations (Jackson, forthcoming). The measure of likeness was the Basic Linear Correlation. In twenty out of twenty-four comparisons (since 1 Henry VI offered two categories of non-Shakespearean material), Arden, 3-8, turned out to be closer to Shakespeare's share of an early collaborative play than to the non-Shakespearean share. This is like tossing a coin and getting twenty heads in twenty-four throws. Such a large deviation from chance expectation has a probability of occurring only once in 650 occasions. The obvious inference to be drawn is that Shakespeare's contributions to all six plays have been fairly accurately determined.

We may also conclude that meticulous analysis of versification, based on the accumulation of quantitative data, remains a key to the understanding of individual playwrights' styles. Approaches to literature come in and out of fashion and much criticism is ephemeral, but good scholarship endures. Oras's work on English dramatic verse stands as a lasting monument to his industry and insight.

\section{References}

Craig, Hugh; Kinney, Arthur F. (eds.) 2009. Shakespeare, Computers, and the Mystery of Authorship. Cambridge: Cambridge University Press.

Gielgud, John 1979. An Actor and his Time. London: Sidgwick \& Jackson.

Groves, Peter L. 2013. Rhythm and Meaning in Shakespeare: A Guide for Readers and Actors. Clayton, Australia: Monash University Publishing.

Harbage, Alfred; rev. Schoenbaum, Samuel; rev. Waggonheim, S. 1989. Annals of English Drama 975-1700. London; New York: Methuen.

Jackson, MacD. P. 1962. Affirmative Particles in "Henry VIII". In: Notes and Queries 207, 372-374.

Jackson, MacD. P. (ed.) 1983. The Revenger's Tragedy: Attributed to Thomas Middleton: A Facsimile of the 1607/8 Quarto. East Brunswick, NJ; London; Toronto: Associated University Presses.

Jackson, MacD. P. 2002a. Pause Patterns in Shakespeare's Verse: Canon and Chronology. In: Linguistic and Literary Computing 17, 37-46. 
Jackson, MacD. P. 2002b. Shakespeare's Richard II and the Anonymous Thomas of Woodstock. In: Medieval and Renaissance Drama in England 14, 17-65.

Jackson, MacD. P. 2003. Defining Shakespeare: "Pericles" as Test Case. Oxford: Oxford University Press.

Jackson, MacD. P. 2006. John Webster, James Shirley, and the Melbourne Manuscript. In: Medieval and Renaissance Drama in England 19, 21-44.

Jackson, MacD. P. 2014. Determining the Shakespeare Canon: "Arden of Faversham" and "A Lover's Complaint". Oxford: Oxford University Press.

Jackson, MacD. P. (forthcoming). Arden of Faversham and Shakespeare's Early Collaborations: The Evidence of Metre.

Jowett, John 1989. Henry Chettle and the Original Text of Sir Thomas More. In: Howard-Hill, T. H. (ed.), Shakespeare and "Sir Thomas More": Essays on the Play and its Shakespearian Interest. Cambridge: Cambridge University Press, 131-149.

Lake, David J. 1983. Three Seventeenth-Century Revisions: Thomas of Woodstock, The Jew of Malta, and Faustus B. In: Notes and Queries 228, 133-143.

Oliphant, Ernest Henry Clark 1927. The Plays of Beaumont and Fletcher: An Attempt to Determine Their Respective Shares and the Shares of Others. New Haven: Yale University Press.

Oras, Ants 1953. "Extra Monosyllables" in Henry VIII and the Problem of Authorship. In: Journal of English and Germanic Philology 52, 198-213.

Oras, Ants. 1960. Pause Patterns in Elizabethan and Jacobean Drama: An Experiment in Prosody. Gainesville, FL: University of Florida Press.

Tarlinskaja, Marina. 1987. Shakespeare's Verse: Iambic Pentameter and the Poet's Idiosyncracies. New York: Peter Lang.

Tarlinskaja, Marina. 2014. Shakespeare and the Versification of English Drama, 15611642. Farnham, Surrey; Burlington, VT: Ashgate.

Taylor, Gary. 1989. The Date and Auspices of the Additions to Sir Thomas More. In: Howard-Hill, T. H. (ed.), Shakespeare and "Sir Thomas More": Essays on the Play and its Shakespearian Interest. Cambridge: Cambridge University Press, 101-129.

Taylor, Gary; Lavagnino, John (eds.) 2007. Thomas Middleton and Early Modern Textual Culture: A Companion to the Collected Works. Oxford: Clarendon Press.

VassarStats: Website for Statistical Computation. vassarstats.net. (last accessed 3 April 2015). 
Wells, Stanley; Taylor, Gary 1987. William Shakespeare: A Textual Companion. Oxford: Clarendon Press.

Wright, George T. 1980. Shakespeare's Metrical Art. Berkeley: University of California Press. 